\title{
THE EFFECT OF ATMOSPHERE PERCEPTION, PERCEIVED VALUE, AND HEDONIC VALUE ON CONSUMER LOYALTY THROUGH THE SERVICE QUALITY OF WARUNK UPNORMAL
}

\author{
Resty Anugrah Kusmarini*)1, Ujang Sumarwan ${ }^{* *}$, and Megawati Simanjuntak ${ }^{* *}$ \\ *) School of Business, IPB University \\ Jl. Raya Pajajaran, Bogor 16151 \\ ${ }^{* *}$ Department of Family and Consumer Sciences, Faculty of Human Ecology, IPB University \\ GMSK Building Floor 2, IPB Dramaga Campus, Bogor 16680
}

\begin{abstract}
This study aimed to analyze the effect of the atmospheric stimulus, perceived value, and hedonic values on consumer loyalty through the service quality of Warunk Upnormal and formulate managerial implications of consumer loyalty. The study used cross-sectional data obtained from a survey using an online open-close ended questionnaire. The data were collected from 300 respondents following the criteria studied through visits of at least two times to Warunk Upnormal and the use of convenience sampling technique. The data were analyzed using Structural Equation Model (SEM) with the help of Lisrel 8.51 software. SEM was used to assess the relationship between atmospheric perception, perceived values, and hedonic values in measurements. Loyalty was analyzed using Customer Loyalty Index (CLI) to connect the factors that encourage the creation of loyalty. The results of this study indicated that atmospheric perception had a significant effect on service quality but had no effect on consumer loyalty. Value perception had a significant effect on service quality but had no effect onconsumer loyalty. Hedonic value had a significant effect on service quality but had no significant effect on consumer loyalty. Meanwhile, service quality had nosignificant effect on consumer loyalty.
\end{abstract}

Keywords: atmosphere perception, consumer loyalty, hedonic value, perceived value, service quality

\begin{abstract}
Abstrak: Penelitian ini bertujuan untuk menganalisis pengaruh stimulus atmosfer, persepsi nilai dan nilai hedonik terhadap loyalitas konsumen melalui kualitas layanan Warunk Upnormal dan merumuskan implikasi manajerial loyalitas konsumen. Desain penelitian yang digunakan adalah cross sectional design dengan metode survey yang dijawab melalui online open-close ended questionnaire. Penelitian ini terdiri dari 300 responden yang sesuai dengan kriteria yang diteliti, yaitu kunjungan minimal 2 kali ke Warunk Upnormal dan menggunakan teknik pengambilan sampel convenience sampling. Data yang terkumpul dianalisis menggunakan Structural Equation Model (SEM) melalui software Lisrel 8.51. SEM digunakan untuk menilai hubungan antara variabel persepsi atmosfer, persepsi nilai dan nilai hedonik dalam pengukuran. Sedangkan untuk analisis loyalitas menggunakan analisis Customer Loyalty Index (CLI) yang digunakan untuk menghubungkan faktor-faktor yang mendorong terciptanya loyalitas. Hasil penelitian ini menunjukkan bahwa persepsi atmosfer memiliki pengaruh yang signifikan dengan kualitas layanan tetapi persepsi atmosfer tidak berpengaruh terhadap loyalitas konsumen. Persepsi nilai memiliki pengaruh yang signifikan dengan kualitas layanan dan tidak berpengaruh terhadap loyalitas konsumen. Nilai hedonik memiliki pengaruh yang signifikan dengan kualitas layanan, namun tidak berpengaruh yang signifikan terhadap loyalitas konsumen. Sedangkan kualitas layanan memiliki pengaruh yang tidak signifikan terhadap loyalitas konsumen.
\end{abstract}

Kata kunci: kualitas layanan, loyalitas konsumen, nilai hedonik, persepsi atmosfer, persepsi nilai

${ }^{1}$ Corresponding author:

Email: anugrahresty83@yahoo.com 


\section{INTRODUCTION}

Business development in the 21st Century has developed very rapidly and is undergoing a continuous metamorphosis. Every business actor in each business category is required to be sensitive to every change that occurs and to place orientation on customer satisfaction as the main goal (Kotler, 2005). No exception applied in the business of serving food and drinks (food service) ranging from small-scale businesses, such as stalls and cafe tents, medium-scale businesses, such as depots, restaurants, and cafes to large-scale businesses such as restaurants in star hotels. Indonesia is a potential market for developing various types of businesses, as can be seen from the population that continues to increase every year. The table of population growth rates in Indonesia is presented in Table 1.

Based on Table 1, the population in Indonesia continues to increase and is a good condition for companies that sell goods or services. Companies in the form of restaurants or cafes certainly have great opportunities to develop their business in Indonesia, because Indonesia has a large population so that the culinary business will continue to grow. Population density is one of the factors of business success, the more dense a location is, the greater the opportunity to get opportunities that enable businesses to run faster to be recognized. Besides, the densely populated location has a faster economic wheel, and this is certainly an outstanding potential for business development, especially in the culinary business. Cumulative growth rate of gross domestic product by business field (percent) 20172018 in Table 2.
The word café comes from French, which means a place that provides food and drinks and has specific characteristics on the product or atmosphere. The development of various types of cafes in Indonesia with various advantages in terms of concepts and flavors of the menu offered is a phenomenon of the trend of various consumer demands. Regulation of the Minister of Culture and Tourism Number PM.87 / HK.501 / MKP2010 concerning the procedures for registering food and beverage service businesses defines restaurants and cafes as businesses providing food and beverages equipped with equipment for the manufacturing, storage, and presentation processes within a place that is not moved.

The emergence of various culinary places causes competition in reaching consumers. Competition in price, service, type of food, and competition exists so that consumers can feel satisfied and are willing to come back in the future. Improving service and product quality to satisfy customers is one of the goals for every company. Many products are produced in various types, qualities, and shapes, all of which are intended to attract customers, so customersmers tend to buy these products.

Therefore, every company is required to be able to create products with the best specifications so that customer satisfaction can be met. This requires the company to be able to reformulate the strategy adopted to improve the ability to compete in serving consumers. Efforts to create and retain consumers should be a top priority for Warunk Upnormal. The right strategy to attract consumers should be carefully arranged, so consumers want to buy products produced by the company. More than that, with all the tips, Warunk Upnormal must also strive so that consumers can be loyal to the products produced.

Table 1. Indonesia population growth rate per Year (2010 to 2017)

\begin{tabular}{|c|c|}
\hline \multicolumn{2}{|c|}{ Indonesian population growth rate per Year (\%) } \\
\hline $2000-2010$ & $2010-2017^{2}$ \\
\hline 1.49 & 1.34 \\
\hline
\end{tabular}

Note: ${ }^{2}$ The projection results of Indonesian Population 2010-2035 (mid-year / June) (BPS, 2018)

Table 2. Cumulative growth rate of gross domestic product by business field (percent) 2017-2018

\begin{tabular}{lccccccc}
\hline GDP of Business & \multicolumn{5}{c}{ 2010 Series GDP Growth Rate } \\
\cline { 2 - 7 } Field (Series 2010) & \multicolumn{5}{c}{ Cumulative Growth Rate (c-to-c) } \\
\cline { 2 - 7 } & Quarterly I & Quarterly II & Quarterly III & Quarterly IV & Quarterly I & Quarterly II & Quarterly III \\
\cline { 2 - 7 } & 7.70 & 7.06 & 7.71 & 9.23 & 12.77 & 10.63 & 9.74 \\
\hline $\begin{array}{l}\text { Food and Beverage } \\
\text { Industry }\end{array}$ & & & & & & \\
\hline
\end{tabular}

Source: BPS (2018) 
Quality provides an impetus for consumers to establish strong bonds with the company. In the long run, this bond allows the company to understand the consumer's expectations and needs carefully. Thus the company can increase consumer loyalty where the company maximizes a pleasant consumer experience and minimizes the experience of a less pleasant consumer. In service quality there are five dimensions proposed by Zeithaml et al. (1990), namely, reliability, responsiveness, assurance, empathy, physical evidence.

Value perception is a concept of expectations that consumers want to achieve based on what they have provided or the overall evaluation of the benefits of a product or service (Ryu et al. 2010). A person's evaluation in the process of consuming a product or service is closely related to the value and pleasure expected by consumers (Babin et al. 1994). Shopping activities consist of two things, namely relating to a task or purpose by having a product and activities that are driven by the pursuit of hedonic values through consumer responses to the shopping experience (Babin et al. 1994).

Consumers enjoy the hedonic value when consuming products related to feelings, fantasies, pleasures and five senses that affect one's emotions. Hedonic value is the overall evaluation of a consumer based on the fulfillment of pleasure (Yistiani etal. 2012). The hedonic value is based on the motivation of consumers to buy because they like it, driven by the desire to achieve a form of pleasure, freedom, delusion, and escape from problems.

According to Kotler and Keller (2009), the definition of service is any action or activity that can be offered by one party to another party, which is intangible and does not result in any ownership. Service is the behavior of producers to meet the needs and desires of consumers for the sake of consumer satisfaction and loyalty.. Kotler also said that the behavior can occur at the time before and after the interaction. In general, high-level services will produce high satisfaction and repeat purchases more often. Consumers use five basic dimensions in assessing service quality, according to Parasuraman et al. (1990) and Sumarwan (2011) are tangibles, reliability, responsiveness, assurance, and empathy.
This research refers to theories related to atmospheric perception, perceived value, and hedonic value to consumer loyalty through service quality in Warunk Upnormal. Puspitasari's research results (2012) showed that exogenous latent variables tangible, reliability, food quality, and perceived value had a significant relationship in forming satisfaction variables. From the SEM analysis results, the CSI calculation value for consumers of Ginyo Duck Rice restaurant was 67.78 percent and the CLI value of this study was 58.11 percent. Managerial implications were suggested for the management of Ginyo Duck Rice restaurant to improve company performance, which will have an impact on increasing customer satisfaction and loyalty.

Khasanah (2012) analyzed thesatisfaction and its effect on the loyalty of travel service consumers. SEM analysis results showed that the five dimensions of service (tangible, reliability, responsiveness, assurance, and empathy) had a significant influence on customer satisfaction and loyalty. This was indicated by the amount of contribution made by service attributes to the service dimension. The tangible dimension gave the most significant influence on satisfaction, which meant that TX Travel Bogor consumers assess the physical and tangible service attributes as the most crucial attribute on satisfaction formation. So it can be concluded that the TX Travel Bogor consumers were satisfied with all the existing service attributes, so that satisfaction had an effect on loyalty.

Ryu et al. (2012) conducted a study on the impact of three elements of foodservice quality (physical environment, food, and service), on restaurant image and perceived value of customers and their effects on customer satisfaction and customer behavior intentions. The analysis was conducted using SEM and showed that the physical environment, food, and service were significant determinants of the restaurant's image. Besides physical quality, food and service were significant predictors of the value perceived by customers. Besides, the perceived value of customers was also a factor that affects customer satisfaction, and customer satisfaction was a predictor of customer behavior intention.

Namkung and Jang (2007) showed that food quality significantly influenced customer satisfaction and behavioral intentions, and behavioral intentions were mediated by customer satisfaction. Further regression analysis showed that food taste and presentation were 
the two most prominent contributions to customer satisfaction and behavioral intention. Subsequently, Namkung and Jang (2008) showed that compelling food presentations, delicious food, seat arrangement, attractive interior design, pleasant background music, reliable service, responsive service, and competent employees were essential attributes in contributing to high satisfaction from visitors.

Some previous studies described illustrated that in the food industry, several variables had an influence on consumer loyalty, although in each region and type of food business had different factors in influencing consumer loyalty. At least, based onthe previous studies, several variables that affect customer loyalty were the dimensions of service quality (tangible, reliability, assurance, responsiveness and empathy), product quality, and perceived value (value and price). This study aimed to analyze the effect of atmospheric perception, perceived value, and hedonic value on the quality of Warunk Upnormal services, analyze the effect of atmospheric perception, perceived value, and hedonic value on consumer loyalty and formulate managerial implications to increase consumer loyalty.

\section{METHODS}

This study was conducted through an online survey. The time needed for distributing the questionnaires was two months via the internet and social media. The data were collected from September to November 2018.

The type of data used in this study were primary data. Primary data was the main source of information needed to answer the research questions. The primary data needed in this study were related to demographic characteristics, the influence of atmospheric perception, perceived value, and hedonic value on consumer loyalty through Warunk Upnormal service quality. The approach taken was descriptive.

The variables used in this study were latent variables consisting of exogenous and endogenous variables. Exogenous variables, namely: a) Atmospheric perception, namely sight (touch), touch (touch), smell (smell), hearing (hearing), temperature (temperature), tempo; b) Perceived value, namely emotional value, social value, and functional value; c) Hedonic values, namely adventure, social, gratification, ideas, roles, and value shopping.

This study used five rating scales with interval scales of (1) strongly disagree, (2) disagree, (3) neutral, (4) agree, (5) strongly agree. The definition of variables and indicators can be seen in Table 3. Sampling or respondent selection was conducted using nonprobability sampling called convenience sampling. It was chosen based on the convenience of the researcher. Data collection in this study was carried out by distributing questionnaires to respondents using Google Form media through domain links disseminated through social media. The data were collected with a guide to a structured questionnaire. The types of questions used were open and closed questions. Data processing in this study was carried out using descriptive analysis of Structural Equation Modeling (SEM) with the help of Lisrel 8.51 software. Meanwwhile, Consumer Loyalty Index (CLI) analysis was used to measure the level of consumer loyalty.

Table 3 Operational definitions of variables and indicators

\begin{tabular}{|c|c|c|}
\hline Latent variable & Operational definitions & Code \\
\hline Atmospheric perception & Everything that makes an impression on consumers based on the five senses & $\mathrm{X} 1-\mathrm{X} 9$ \\
\hline Perceived value & $\begin{array}{l}\text { Consumer assessment performed by comparing the benefits/benefits to be } \\
\text { received }\end{array}$ & $\mathrm{X} 10-\mathrm{X} 15$ \\
\hline Hedonic value & $\begin{array}{l}\text { Assessments are based on experience and affective matters and mostly } \\
\text { relate to the elements/attributes of products or services that are visible }\end{array}$ & $\mathrm{X} 16-\mathrm{X} 22$ \\
\hline Service quality & $\begin{array}{l}\text { Efforts to meet the needs and desires of consumers and the accuracy of the } \\
\text { delivery in balancing consumer expectations }\end{array}$ & X23-X35 \\
\hline Consumer loyalty & Consumers still use a brand of a particular product & Y1-Y3 \\
\hline
\end{tabular}


Effects of Atmospheric Perception on Service Quality

The atmosphere is an atmosphere that is planned to meet the needs of the target market and, at the same time, create an attraction attracting consumers to buy. Store atmosphere affects the emotional state of the buyer that causes or influences the purchase. Emotional conditions would make two dominant feelings, feeling happy, and arouse desire (Meldarianda and Lisan, 2010). There were several factors in the store's atmosphere that affect emotions, behaviour, or purchasing decisions. These factors included exterior, layout, and interior (Kusumowidagdo, 2010; Nofiawati and Yuliandi, 2014). Based on the explanation above, it can be concluded that the atmospheric perception was very influential for the quality of service.

H1: atmosphere perception has a significant influence onservice quality.

Effect of Atmospheric Perception on Consumer Loyalty

The atmosphere statistically has an influence on consumer loyalty. This was supported by the research conducted by Chen and Hsieh (2011), which stated that environmental dominance could significantly influence consumer purchasing behaviour, which would not only have an impact on retail company theory but also closely correlate with consumer loyalty. Store environment or store atmosphere was considered to be one of the reasons consumers were loyal even though it was only specific to certain market segments (Yavas and Babakus, 2009). The results showed that store atmosphere, such as color, lighting, interior decoration, music, and fragrances could influence consumer decisions and store image (Turley and Milliman, 2000). It was further explained that the store atmosphere had an enormous influence on the evaluation and behavior of consumers. Because it was considered an essential part in shaping the shopping experience that influenced the decision to visit a store (Kotler, 1972). According to Kocamaz (2003), marketers needed to pay attention to store atmosphere because it had an influence on the form of purchase and customer satisfaction, where customer satisfaction was a predictor of consumer loyalty.
H2: Atmosphere perception has a significant influence on consumer loyalty.

\section{Effect of Value Perception with Service Quality}

Perceived value was considered as the recognition and appreciation of customers for the usefulness of a product provided by service providers who could meet their expectations (Foster, 2004). In the context of service management, an organization's ability to use responsiveness, assurance, and empathy in providing services would increase customer value perceptions; this could lead to higher customer satisfaction (Sureshchandar, 2000). Also, Caruana et al. (2002) conducted in-depth interviews with 80 respondents from audit firms and found that service quality was positively correlated with perceived value. Research in this field revealed that the relationship between service quality and customer satisfaction was greatly moderated by perceived value. For example, Eggert and Ulaga (2002) conducted research on customer satisfaction based on 301 employees in US organizations. This study found that the correct application of service quality featured (i.e., guarantees, empathy, reliability, responsiveness, and physical evidence) had increased the value of individual perceptions about quality features. As a result, it can lead to increased customer satisfaction.

H3: Perceived value has a significant influence on and service quality

\section{Effect of Value Perception on Consumer Loyalty}

Value perceptions was used to measure performance,control differences between respondents, and compare products and services with high and low prices (Lancaster, 1971). Thus it is expected that there is a positive relationship between perceived value and perceived customer satisfaction. Consumer satisfaction was influenced by perceived value, and loyalty was influenced by customer satisfaction (Wasseso, 2012). The effect of perceived value on the formation of consumer loyalty did not occur directly, but through customer satisfaction (Ryu et al. 2008). Research conducted by Endah (2009) mentioned that perceived value could affect customer satisfaction which in turn would form loyalty. 
H4: Perceived value has a significant influence on consumer loyalty.

\section{Effect of Hedonic Value with Service Quality}

According to Fajriah (2014), hedonic values were people oriented. Hedonic values were formed when customers feel comfortable with the company and get surprised. Providing accurate information and benefits that are commensurate with prices were offset by good service and the friendly atmosphere provided by the company (Hanzaee and Khonsari, 2011).

H5: Hedonic values has a significant influence on service quality.

\section{Effect of Hedonic Value on Consumer Loyalty}

High hedonic values affect consumer satisfaction emotionally. Anderson et al. (2014) assessed that experience/hedonic value had a positive influence on consumer loyalty, so producers need to consider the level of implementation carefully. In a study conducted by Kim (2006), consumers who had a hedonic attitude tended to have a higher level of satisfaction compared to consumers who had a low hedonicattitude. Subagio (2011) and Kuikka and Laukkanen (2012) stated that hedonics had a significant positive effect on consumer loyalty. Hedonic motivation created by a person's emotions because internal and external factors greatly affect consumer loyalty.
H6: Hedonic values has a significant influence on customer loyalty.

\section{Effect of Service Quality on Consumer Loyalty}

Service quality was one of the variables that influenced consumer loyalty. Helgeseen et al. (2009) asserted that service quality and customer satisfaction were two things that should be examined together to determine its effect on customer loyalty. There are major differences between the research model conducted by several previous researchers. Research conducted by Chen and $\mathrm{Hu}$ (2009) in the café outlet industry considered that the construct of service quality and satisfaction did not affect loyalty. The study included relational benefits as latent variables in the model. Service quality could also affect customer satisfaction so that service quality could be a measure of whether consumers would remain consumers or move to other service providers (Ryu et al. 2008).

H7: Service quality has a significant influence on customer loyalty.

Zhang and Prybutok (2005) showed that desire could predict behavior so that it could be said that the quality of service perceived by consumers had implications on purchasing desires. Physical involvement in the dimensions of service quality also influenced consumer perceptions of product quality, which could then lead to customer satisfaction and a desire to buy. These show that indirectly, product quality could affect future customer loyalty. The conceptual framework of the study can be seen in Figure 1.

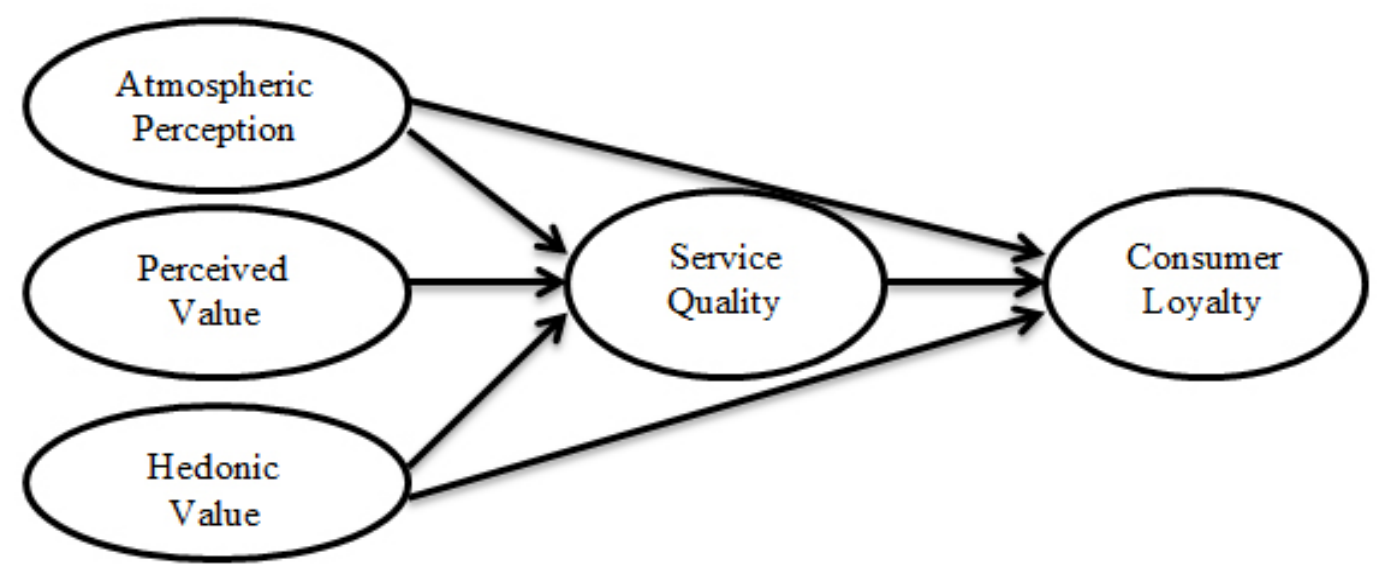

Figure 1. Conceptual framework 


\section{RESULTS}

\section{Validity test}

A validity test is done to see whether the research instrument or questionnaire used is valid or invalid using product-moment correlation. The testing of the research instrument or questionnaire was carried out using SPSS software. A variable or attribute is said to be valid or not based on the r-count value compared to the $\mathrm{r}$-table or the probability value ( $\mathrm{p}$-value). The attribute is declared valid if the correlation coefficient (r-count value) is greater than $\mathrm{r}$-table or the p-value is less than 0.05 The $r$-table for $n=30$ is 0.361 . Thus all $r$-counts (correlation coefficient) are obtained from processing this research data more than $\mathrm{r}$-table except indicators $\mathrm{X} 6, \mathrm{X} 17, \mathrm{X} 18, \mathrm{X} 20, \mathrm{X} 21, \mathrm{X} 22, \mathrm{Y} 2$, and Y3.

In this test, the indicator is still included in the invalid category because it has an $r$-count $<$ r-table. Some of the indicator variables are then subjected to language simplification so that they can be included in the next stage, namely the reliability test. In addition to the indicator variables that have been mentioned, all indicators included in this study already meet the requirements so that they can be said to be valid.

\section{Reliability Test}

The reliability test is intended to measure the level of consistency of research instruments. In this study, it was analyzed using SPSS software and expressed by looking at the value of Cronbach's alpha $(\alpha)$. A variable is declared reliable if it gives a Cronbach's alpha value> 0.6 (Latan and Ghozali, 2012).

The reliability test results can be seen that there is one latent variable that has Cronbach's alpha $<0.6$, namely the hedonic value, as presented in Table 4. Whereas for other latent variables has Cronbach's alpha> 0.06, it shows that the question items or indicator variable which describes atmospheric variables, values, service quality, and customer loyalty have fulfilled the requirements so that they can be said to be reliable.

\section{Overall Model Fit Test Results}

According to Wijanto (2008), regarding the SEM model compatibility test, there is no best statistical test that can explain the predictive "strength" of a model.Therefore, the researchers provide several alternative GOF measures that can be used together or in combination to assess the degree of suitability of a model. Model compatibility test can be seen from df, Chi-square, p-value, RMSEA, GFI, and AGFI as presented in Table 5.

Table 4. Reliability test

\begin{tabular}{lcccc}
\hline Latent Variable & Cronbach's alpha & Alpha Standard Value & Explanation & Number of question items \\
\hline Atmospheric & 0.782 & 0.6 & Reliable & 9 \\
Value & 0.816 & 0.6 & Reliable & 6 \\
Hedonic Value & 0.227 & 0.6 & Unreliable & 7 \\
Service Quality & 0.933 & 0.6 & Reliable & 13 \\
Consumer Loyalty & 0.637 & 0.6 & Reliable & 3 \\
\hline
\end{tabular}

Table 5. Overall model fit test results

\begin{tabular}{lccc}
\hline Goodness of Fit & Cut off Value & Result & Explanation \\
\hline RMR (Root Mean Square Residuan) & $\leq 0.1$ & 0.059 & Good Fit \\
RMSEA (Root Mean Square Error of Approximation) & $\leq 0.08$ & 0.091 & Marginal Fit \\
GFI (Goodness of Fit Index) & $\geq 0.90$ & 0.91 & Good Fit \\
AGFI (Adjusted Goodness of Fit Index) & $\geq 0.90$ & 0.84 & Marginal Fit \\
NFI (Normed Fit Index) & $\geq 0.90$ & 0.89 & Marginal Fit \\
NNFI (Non-Normed Fit Index) & $\geq 0.90$ & 0.87 & Marginal Fit \\
CFI (Comparative Fit Index) & $\geq 0.90$ & 0.92 & Good Fit \\
IFI (Incremental Fit Index) & $\geq 0.90$ & 0.92 & Good Fit \\
\hline
\end{tabular}


According to the GOF results obtained, four GOF measurements show a marginal fit match, namely GFI, AGFI, NFI, and RFI. Whereas GOF measurements included in good fit measures include RMR, RMSEA, NNFI, CFI, and IFI.

\section{Structural Model Fit}

In this study, the significance test used a significance level of 0.05 (95 percent confidence level). Then at the 0.05 significance level, the T-value of each coefficient of the structural equation must be higher than 1.96. If there is a T-Test value lower than 1.96, then there is an insignificant relationship or cannot explain the latent variable pointed by the arrow. SEM structural model (after elimination) in Figure 2.

\section{Measurement Model Match Test}

The fit criteria of the measurement model was measured based on the validity of the indicator variables against their latent variables. An indicator variable is said to be valid if it has a standardized loading factor more than the tolerable loading factor limit that is $\geq 0.5$ and has a t-value of above 1.96 (Igbaria et al., 1997). The suitability test of the measurement model after elimination can be seen in Table 6 .

Based on the results in the standardized loading factor diagram and t-value diagram it can be seen that all variables meet the validity requirements where the value of the standardized loading factor is more than 0.5 , and the $t$-value is above 1.96 or included in the significant category.

\section{Hypothesis Test}

The relationship between variables in this study could be discovered by doing a significance test (t-test), where the confidence level used was 95 percent (a significance level of 0.05 ) and a t-value of 1.96. In this study, it was found out that only the value perception variable had an influence on service quality. Besides, from the influence test, it was found out that service quality influenced the formation of consumer loyalty. Table 7 summarizes the effect of exogenous latent variables on their endogenous latent variables.

Hypothesis 1. Based on the analysis of the structural model, the $t$-value is 0.54 . This means that the value does not meet the $t$-value requirement $\geq 1.96$ so that the perception of the atmosphere does not affect the quality of service, thus hypothesis one is rejected. Respondents who have felt the experience of eating and drinking at Warunk Upnormal may not necessarily be able to feel good quality service. Pratamatya (2015) needs changes that support in real terms, such as changes in the design of store markers that are more prominent and attract the attention of visitors, building maintenance, arranging the room to always meet the comfort standards of the existing room (temperature standards, noise level standards and others).

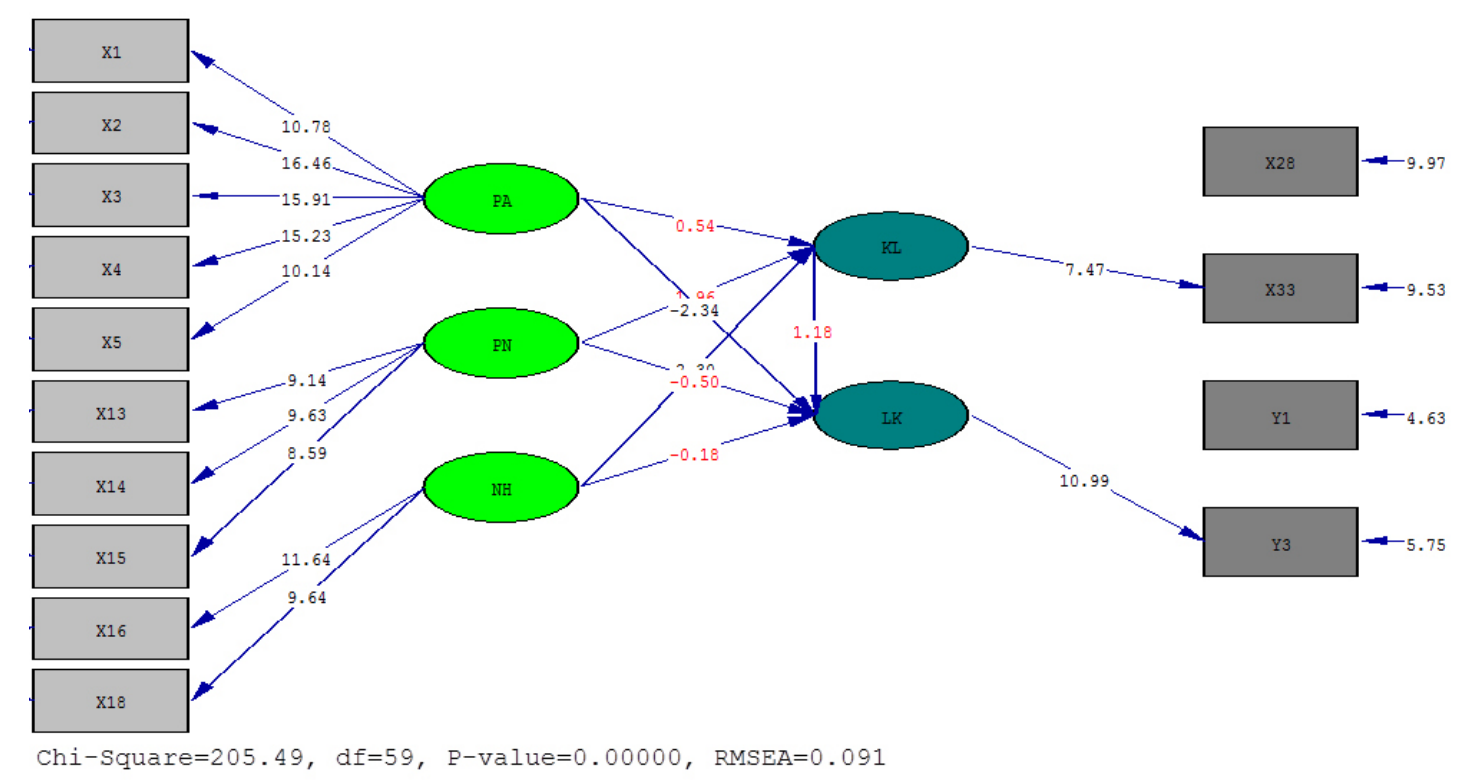

Figure 2. SEM structural model (after elimination) 
Table 6. Test the suitability of the SEM measurement model

\begin{tabular}{llccc}
\hline Latent Variable & \multicolumn{1}{c}{ Indicator Variable } & Loading Factor & t-value & Explanation \\
\hline Atmospheric Perception & X1. Room color & 0.61 & 10.78 & Valid \\
& X2. Decoration items & 0.82 & 16.46 & Valid \\
& X3. Display of floors, walls and ceilings & 0.80 & 15.91 & Valid \\
& X4. Furniture & 0.78 & 15.23 & Valid \\
& X5. The scent of the room & 0.57 & 10.14 & Valid \\
Perceived Value & X13. Product price & 0.59 & 9.14 & Valid \\
& X14. Product and service & 0.68 & 9.63 & Valid \\
& X15. Service quality & 0.62 & 8.59 & Valid \\
Hedonic Value & X16. Different sensation & 0.71 & 11.64 & Valid \\
& X18. Improve mood & 0.58 & 9.64 & Valid \\
& X28. The services provided are appropriate & 0.54 & & Valid \\
Consumer Quality & X33. Friendly employees & 0.56 & 7.47 & Valid \\
& Y1. Recommend to others & 0.85 & & Valid \\
& Y2. Repurchase & 0.82 & 10.99 & Valid \\
\hline
\end{tabular}

Note: if the standardized loading factor (SLF) value $\geq 0.5$ and T-count $>1.96$, the indicator variable has good validity.

Table 7. Hypothesis test result

\begin{tabular}{lccc}
\hline Effect & Loading Factor & t-value & Explanation \\
\hline Atmospheric perception on service quality & 0.10 & 0.54 & Not Significant \\
Atmospheric perception on consumer loyalty & -0.72 & -2.34 & Significant \\
Perceived value on service quality & 0.28 & 1.96 & Significant \\
Perceived value on consumer loyalty & -0.21 & -0.50 & Not Significant \\
Hedonic value on service quality & 0.62 & 2.30 & Significant \\
Hedonic value on consumer loyalty & -0.18 & -0.18 & Not Significant \\
Service quality on consumer loyalty & 1.63 & 1.18 & Not Significant \\
\hline
\end{tabular}

Hypothesis 2. Based on the research results obtained, it is known that the relationship of atmospheric perception has a significant negative effect and has a t-value of -2.34 on consumer loyalty. This research is supported by the statement of Levy and Weitz (2001) in Dessyana (2013) The store atmosphere is the creation of a shop atmosphere through visuals, arrangement, light, music, and aroma that can create a comfortable purchasing environment so that it can influence the perceptions and emotions of customers to make purchases. The scope of the store atmosphere can be grouped into four parts, namely: exterior (outside the store), interior (inside the store), interior point of interest display, and store layout. These four elements become a series of strategies that involve various salon attributes to attract and influence customer emotions that further enhance customer loyalty. Measuring customer satisfaction or dissatisfaction is directly affected by the effective (positive or negative) feeling of consumers.
Hypothesis 3. Based on the research results obtained, it was identified that the relationship between perceived value and service quality had a t-value of 3.49 . This meant that perceived value had a positive and significant effect on service quality. This was supported by Caruana et al. (2002) who conducted in-depth interviews with 80 respondents from audit firms and found that service quality was positively correlated with perceived value. Hypothesis 4. Based on the research results obtained, it was known that the relationship of perceived value and consumer loyalty had a $t$-value of -0.25 . This meant that perceived value had no effect on consumer loyalty. Thus hypothesis four is rejected. This study is different from the previous study conducted by Hapsari et al. (2015), which stated that there was a relationship between perceived value and consumer loyalty. However, perceived value only had a weak influence on consumer loyalty, which can be chosen from the path coefficient (0.160). Weak path coefficients indicated that consumer loyalty might also be influenced by other constructs that were not included in the model or perceived value, which not only directly affected consumer loyalty, but 
also had an indirect effect. Thus themediating effect of consumer involvement on the relationship between perceived value and consumer loyalty was proposed. Baron and Kenny's (1986) research results showed that customer involvement mediated the relationship between perceived value and customer loyalty.

Hypothesis 5. Based on the results of the research conducted, the relationship between hedonic values and service quality had a t-value of 0.82 . This meant that the hedonic value did not have a significant effect on servicequality provided by Warunk Upnormal. Thus hypothesis five is rejected. According to Fajriah (2014), in the face of increasingly fierce competition between companies, the company launched a variety of strategies to lure its potential and existing customers, so that they remain loyal. One important factor that requires special attention is the service quality provided by the company to customers. In other words, quality is a consistent and efficient tip for giving customers what they want and expect. Quality service has been felt as a necessity. Currently, companies are required to continue to adjust the demands of change according to the wishes (needs) of customers (Parasuraman et al. 1998).

Hypothesis 6. Based on the results of the research conducted, the relationship between hedonic values and consumer loyalty had a t-value of -0.61 . This meant that the hedonic value did not have a significant effect on consumer loyalty. Thus hypothesis six is rejected. The result of this study is in line with the result of research by $\mathrm{Hu}$ and Chuang (2012) that showed that the hedonic value did not significantly affect loyalty. It was revealed, the weak direct hedonic effect on loyalty was suspected because hedonic values required intermediate variables, such as customer satisfaction in influencing consumer loyalty.

Hypothesis 7. Based on the results of the research conducted, the relationship between service quality and customer loyalty had a t-value of 1.18 . This meant that the value did not meet the requirement of t-value $\geq 1.96$, so that the quality of service did not significantly affect customer loyalty. Thus the hypothesis seven is rejected. The result of this study is in line with the research of Aryani and Rosinta (2010) which showed that the effect of the quality of service produced was insignificant, so the hypothesis was rejected. Thus service quality did not guarantee consumers would be loyal, because service quality had a very weak effect on loyalty. Meanwhile, the rest was explained by other variables. The cause of the inferior service quality can be analyzed because there were other factors (outside the service quality factor) that had a stronger influence on the creation of loyalty compared to the service quality factor. According to Gupta et al. (2007), there were three basic performances in a restaurant besides service quality, namely, food quality and price.

\section{Indirect Influence}

Indirect effects are the effects of exogenous variables on endogenous variables that occur through others. Endogenous variables were contained in the causal model being analyzed. The number of indirect effects is presented in Table 8.

The magnitude of the indirect effect of the exogenous variable on endogenous variables is the doubling of the path coefficient value of the exogenous variable to the endogenous variable with the path coefficient value of the endogenous variable to other endogenous variables.

\section{Consumer Loyalty Index (CLI)}

The results of SEM analysis were used to measure the level of consumer loyalty to atmospheric perception, perceived value, hedonic value, and service quality to Warunk Upnormal, followed by an analysis of Customer Loyalty Index (CLI). In this study, the assessment of Warunk Upnormal consumer loyalty on indicator attributes was based on the percentage of respondents who answered each question with a value of "4" or "agree" and "5" or "strongly agree" (top two boxes). The weighted value of CLI for each indicator variable can be seen in Table 9.

Based on Table 9, it was known that the Warunk Upnormal consumer loyalty index was 55.69 percent. This value was included in the neutral or average category. From the results obtained, there needs to be a comprehensive evaluation conducted by Warunk Upnormal to create high customer loyalty. For example, Warunk Upnormal applies a membership card to consumers who have made large purchases or consumers who make visits twice a month and the card will be handy for consumers in subsequent purchases (for example, consumers get a 25 percent discount on each subsequent purchase) and allow consumers to return to Warunk Upnormal soon. The highest score obtained on the loyalty indicator was that consumers will recommend Warunk Upnormal to others within the next month. 
Table 8. Indirect Influence

\begin{tabular}{lc}
\hline Variable & Indirect Effect \\
\hline Atmospheric Perception to Consumer Loyalty & 0.16 \\
Perceived Value to Consumer Loyalty & 0.45 \\
Hedonic Value to Consumer Loyalty & 1.01 \\
\hline
\end{tabular}

Table 9. Consumer loyalty index (CLI)

\begin{tabular}{lcccc}
\hline Indicator & Big Influence & Weight & CLI (\%) & CLI Per Indicator (\%) \\
\hline $\begin{array}{l}\text { I will recommend Warunk Upnormal to others } \\
\text { within the next 1 month }\end{array}$ & 0.85 & 0.50 & 52 & 26 \\
$\begin{array}{l}\text { I will still make a purchase even if the price of the } \\
\text { product goes up }\end{array}$ & 0.82 & 0.49 & 64 & 31.36 \\
$\begin{array}{l}\text { Total } \\
\text { CLI }\end{array}$ & 1.67 & & & 57.36 \\
\hline
\end{tabular}

\section{Managerial Implications}

As for some managerial implications that can be done by Warunk Upnormal: (a) Always maintain cleanliness and repair damaged furniture and paint the stained walls. (b) Increase the number of tables and chairs. (c) Update the display of walls and information boards regularly with more exciting content. Warunk Upnormal Management must try to create an atmospheric strategy that can meet the expectations of their potential customers. Warunk Upnormal must also be responsive and flexible in following the ever-changing trends in market segments. (d) The results of the study illustrated that Warunk Upnormal management has built interactions with visitors through comfortable products and services, making a good impression, price, and the quality of service that is always consistently effective in creating positive emotions in the minds of consumers. (e) Warunk Upnormal still needs to innovate to continue attracting consumers, for example innovating in producing new menus every month that can improve consumer mood. (f) Warunk Upnormal management still needs to interact with visitors by providing friendly service, providing good menu and price information, paying attention to the needs of consumers, and willing to apologize when making mistakes. These are the key to good service quality.

\section{CONCLUSIONS AND RECOMMENDATIONS}

\section{Conclusions}

Based on the analysis results, it can be concluded that the atmospheric perception did not significantly influence service quality. Value perception had a significant effect on service quality. The hedonic value had a significant effect on service quality. The atmospheric perception had a significant effect on consumer loyalty. The value perception did not significantly influence consumer loyalty. The hedonic value did not significantly influence consumer loyalty. Service quality did not significantly influence consumer loyalty. Service quality was not an important factor in the achievement of loyalty due to the characteristics of respondents used in this study were relatively homogeneous, namely students. Therefore, the service quality doid not much affect loyalty.

\section{Recommendations}

Several suggestions that can be given were that the management of Warunk Upnormal needs to pay special attention to the physical facilities found in the Warunk Upnormal café, both checking decoration items, furniture, the appearance of walls and ceilings regularly. Distributing questionnaires to respondents should be done directly in the place of research so that consumers can provide a more objective assessment. Use data collection techniques other than questionnaires, which can provide data with a better level of accuracy, and if the results found are not significant, then researchers need to re-interview some of the respondents beforehand. In this study the variables studied were the effect of atmospheric perception, perceived value and hedonic value on consumer loyalty through service quality, it is hoped that for further research the variables studied could be drawn from other theories that shape consumer loyalty, such as using the marketing mix or $7 \mathrm{P}$ theory in marketing. So that the results obtained can be more diverse and strengthen current research. 


\section{REFERENCES}

Anderson KC, Knight DK, Pookulangara S, Josiam B. 2014. Influence of hedonic and utilitarian motivation on retailer loyalty and purchase intention: a facebook perspective. Journal Retailing and Consumer Service 21(2014): 773-779. https://doi.org/10.1016/j. jretconser.2014.05.007.

Aryani D, Rosinta F. 2010. Pengaruh kualitas layanan terhadap kepuasan pelanggan dalam membentuk loyalitas pelanggan. bisnis \& birokrasi. Jurnal Ilmu Administrasi dan Organisasi 17(2): 114126.

Babin BJ, Darden WR, Griffin M. 1994. Work and or fun: measuring hedonik and utilitarian shopping value. The Journal of Customer Research 20(4): 644-656. https://doi.org/10.1086/209376.

Baron RM, Kenny DA. 1986. The moderator-mediator variable distinction in social psychological research: conceptual, strategic and statistical considerations. Journal of Personality and Social Psychology 51(6): 1173-1182. https:// doi.org/10.1037/0022-3514.51.6.1173.

[BPS] Badan Pusat Statistik Bogor. 2018. Jumlah Penduduk Kota Bogor. https://bogorkota.bps. go.id/ [Jan 2018].

Caruana A, Malta M. 2002. The effects of service quality and the mediating role of customer satisfaction. European Journalof Marketing36(7/8): 811-828. https://doi.org/10.1108/03090560210430818.

Chen SH, Hsieh T. 2011. The effect of atmosphere on customer perceptions and customer behavior responses in chain store supermarkets. African Journal of Business Management 5(2): 1005410066. https://doi.org/10.5897/AJBM10.608.

Eggert A, Ulaga W. 2002. Customer perceived value: A substitute for satisfaction in business markets?. Journal of Business and Industrial Marketing 17 (2) (3): 107-118. https://doi. org/10.1108/08858620210419754.

Endah PA. 2009. Pengaruh perceived value pada loyalitas konsumen yang dimediasi oleh kepuasan konsumen dan dimoderatori oleh gender. Jurnal Manajemen dan Bisnis 2(2009): 43-59.

Fajriah F. 2014. Analisis pengaruh hedonic value, persepsi manfaat dan persepsi kredibilitas terhadap kualitas layanan dan dampaknya pada minta beli ulang dengan mediasi customer value (Studi kasus pada oriflame produk lipstik di kota Semarang). Jurnal Sains Pemasaran Indonesia
13(1): 74-96.

Foster ST. 2004. Managing Quality: An Integrative Approach. New Jersey: Prantice Hall.

Hanzaee KH, Khonsari Y. 2011. A review of the role of hedonic and utilitarian Values on customer's satisfaction and behavioral intentions. Interdisciplinary Journal of Research in Business 1(5): 34-45.

Harianto D, Subagio H. 2013. Analisa pengaruh kualitas pelayanan, brand image dan atmosfer terhadap loyalitas konsumen dengan kepuasan konsumen sebagai variabel intervening konsumen kedai Deja-Vu Surabaya. Jurnal Manajemen Pemasaran 1(1): 1-8.

Helgesen O, Jhon IH, Erik N. 2009. Impact of store and chain image on the quality satisfaction loyalty process in petrol reatiling. Journal of Retailing and Consumer Service 17(2): 109-118. https:// doi.org/10.1016/j.jretconser.2009.11.001.

Hu, Chuang. 2012. A study of the relationship between the value perception and loyalty intention toward an e-retailer website. Journal of Internet Banking and Commerce 17(1).

Igbaria M, Zinatelli N, Cragg P, Cavaye LM. 1997. Personal computing acceptance factors in small firms: a structural equation model. MIS Quarterly 21(3): 279-302. https://doi.org/10.2307/249498.

Khasanah G. 2012. Analisis kepuasan dan pengaruhnya terhadap loyalitas pelanggan jasa tx travel Bogor [tesis]. Bogor: Institut Pertanian Bogor.

Kim HS. 2006. Using hedonic and utilitarian shopping motivations to profile inner city consumer. Journal of Shopping Center Research 13(1): 57-79.

Kocamaz T, Yalcin M. 2003. The effects of store athmosphere attributes on store loyalty intention of hypermarket/supermarket customers.http:// dosya.marmara.edu.tr/ikf/iib-dergi/2003-12/2003_yalcin-kocamaz.pdf [Jan 2018].

Kotler P. 1973. Atmospherics as a marketing tool. Journal of Retailing 49(4):48-64.

Kotler P. 2005. Manajemen Pemasaran. Terjemahan oleh Benyamin Molen. Jilid 1 dan 2. Edisi ke 11. Jakarta: PT. Indeks Kelompok Gramedia.

Kotler P, Keller KL. 2009. Manajemen Pemasaran Jilid 1 Edisi 13. Jakarta: Erlangga.

Kuikka A, Laukkanen T. 2012. Brand loyalty and the role of hedonic value. Journal of Product and Brand Management 21(7): 529-537. https://doi. org/10.1108/10610421211276277.

Kusumowidagdo A. 2010. Pengaruh desain atmosfer 
ritel terhadap perilaku belanja.Jurnal Manajemen Bisnis 3(1): 17-32.

Latan H, Ghozali I. 2012. Partial Least Square: Konsep, Teknik dan Aplikasi SmartPLS 2.0 M3. Semarang: Badan Penerbit Universitas Diponegoro.

Levy W. 2001. Retailing Management, 4th edition. New York: Mc.Graw Hill, Irwin.

Meldarianda R. Lisan H. 2010 Pengaruh store atmosphere terhadap minat beli konsumen pada resort café atmosphere Bandung. Jurnal Bisnis dan Ekonomi (JBE) 17(2): 97-108.

Namkung Y, Jang S. 2007. Does food quality really matter in restaurants? its impact on customer satisfaction and behavioral intentions. Journal of Hospitality \& Tourism Research 31(3): 387-409. https://doi.org/10.1177/1096348007299924.

Nofiawati N, Yuliandi B. 2014. Pengaruh store atmosphere terhadap keputusan pembelian konsumen pada outlet nyesnyes Palembang [tesis]. Palembang: Program Studi Manajemen. Fakultas Ekonomi. Universitas Sriwijaya.

Parasuraman A, Zeithaml VA, Berry LL. 1990. Delivery Quality Service Balancing Customer Perception and Expectation. New York: Free Pass Collier Macmillan Publisher.

Parasuraman A, Zeithaml VA, Berry LL. 1998. SERVQUAL : A multiple item scale for meansuring consumer perseption of service quality. Jurnal of Retailing 6(1):12-40.

Pramatatya V. 2015. Pengaruh persepsi atmosfer terhadap keputusan pembelian ulang pengunjung di rumah kopi Ranin Bogor [tesis]. Bogor: Institut Pertanian Bogor.

Puspitasari K. 2012. Analisis kepuasan dan loyalitas pelanggan restoran nasi bebek ginyo di Jakarta. [tesis]. Bogor: Institut Pertanian Bogor.

Ryu K. 2008. The relationship among overall quickcasual restaurant image, perceived value, customer satisfaction and behavioral intentions. International Journal of Hospitality Management 27: 459-469. https://doi.org/10.1016/j. ijhm.2007.11.001.

Ryu K. Han H. Jang SS. 2010. Relationship among hedonic and utilitarian values, satisfaction and behavioral intentions in the fast-casual restaurant industry. International Journal of Contemporary Hospitality Management 22(3): 416-432.

Ryu K, Lee H, Kim WG. 2012. Influence of the quality of physical environment, food, and service on restaurant image, value, customer satisfaction and behavioral intentions. International Jurnal of Contemporary Hospitality Management 24(2):200-223.

Subagio H. 2011. Pengaruh atribut supermarket terhadap motivasi belanja hedonik motifasi belanja utilitarian dan loyalitas konsumen. Jurnal Manajemen Pemasaran Prodi Manajemen Bisnis, Fakultas Ekonomi, Universitas Kristen Petra 6(1): 8-21. https://doi.org/10.9744/ pemasaran.6.1.8-21.

Sumarwan U. 2011. Perilaku Konsumen: Teori dan Penerapannya dalam Pemasaran. Jakarta: Ghalia Indonesia.

Sureshchandar GS. 2000. The relationship between service quality and customer satisfaction a factor specific approach. Journal of Service Marketing 16(4): 363-379.

Turley LW. Milliman RE. 2000. Atmospheric Affects on Shopping Behaviour a Review of the Experimental. Journal of Business Research 49(2): 193-211. https://doi.org/10.1016/S01482963(99)00010-7.

Wasseso S. 2013. The influence of perceived service quality, mooring factor and relationship quality on customer satisfaction and loyalty. Journal Social and Behavioral Sciences 81(2013): 306-310. https://doi.org/10.1016/j.sbspro.2013.06.433.

Wijanto SH. 2008. Structural Equation Modeling dengan LISREL 8.8: Konsep dan Tutorial. Yogyakarta: Graha Ilmu.

Yavas U. Babakus E. 2009. Retail store loyalty: a comparison of two customer segments. International Journal of Retail and Distribution Management 37(6): 477-492. https://doi. org/10.1108/09590550910956223.

Yistiani NNM. Yasa NNK. Suasana, I Gede AKG. 2012. Pengaruh atmosfer gerai dan pelayanan ritel terhadap nilai hedonik dan pembelian impulsif pelanggan matahari departemen store duta plaza di Denpasar. Jurnal Manajemen Bisnis, Strategi Bisnis dan Kewirausahaan 6 (2): 139-149.

Zeithaml V. 1988. Consumer perceptions of price, quality, and value: a meansed model and synthesis of evidence. Journal of Marketing 60 (2): 31-46. https://doi.org/10.2307/1251929.

Zhang X. Prybutok VR. 2005. A consumer perspective of a service quality. IEEE Transactions on Engineering Management 52(4): 461-477. https://doi.org/10.1109/TEM.2005.856568. 